\title{
The role of animal feeding trials for the nutritional and safety assessment of feeds from genetically modified plants - Present stage and future challenges
}

\author{
G. Flachowsky ${ }^{1}$ and C. Wenk ${ }^{2}$ \\ ${ }^{1}$ Institute of Animal Nutrition, Friedrich-Loeffler-Institute (FLI), \\ Federal Research Institute of Animal Health \\ Bundesallee 50, D-38116 Braunschweig, Germany \\ ${ }^{2}$ Former Institute of Animal Sciences, ETH Zurich, ETH-Zentrum \\ CH-8092 Zurich, Switzerland
}

(Received: 7 May 2010; accepted 14 May 2010)

\begin{abstract}
The world's population is still growing up and asking for more and better food. High yielding plants with low external inputs should be the main aim of plant breeding to meet the higher demand for man and animal. Apart from traditional breeding plant biotechnology seems to have a certain potential to contribute to this objective. Safety and nutritional studies with such modified plants are the most important prerequisites for public acceptance of derived feed and food.

The first step for safety and nutritional assessment of modified plants is the compositional analysis of potential food/feed and including the newly expressed proteins and other new constituents and the comparison with conventional counterparts. In vitro studies and experiments with laboratory animals are the next steps for assessments. Feeding studies with target animals are of special concern for nutritional assessment and are considered in more detail in the present paper.
\end{abstract}

KEY WORDS: genetically modified plants (GMP), nutritional and safety assessment, digestibility, types of feeding studies

\footnotetext{
${ }^{1}$ Corresponding author: e-mail: gerhard.flachowsky@t-online.de
} 


\section{INTROUCTION}

Sustainability in feed and food production is a key challenge for agriculture. In the future there will be strong competition for arable land and further limited resources such as fossil carbon-sources, water, some minerals (such as phosphorus) between feed/food, fuel, fibre, areas for settlements and natural protected areas. According to the FAO (2009) human population will globally increase from currently about 6.7 to 9 billion people (about $40 \%$ more) 2050 (Steinfeld et al., 2006), but the estimated need for meat and milk will nearly double during this time (Table 1).

Table 1. Challenges for animal production or "Livestock's long shadow" (Steinfeld et al., 2006)

\begin{tabular}{lccc}
\hline Year & Presently & 2050 & Percent to presently \\
\hline World population, billion & 6.5 & 9.0 & 138 \\
Meat production, million ton & 229 & 465 & 203 \\
Milk production, million ton & 580 & 1043 & 180 \\
\hline
\end{tabular}

Presently the global growth rate is estimated with 2.7 and $1.8 \%$ for meat and milk, respectively yearly (FAO, 2009) and varies between different regions (more than 5\% in some countries in East and Southeast Asia and less than -2\% in some African countries). In addition there are large differences in the per capita estimated consumption of livestock products per year (e.g., $125.6 \mathrm{~kg}$ meat in the USA and $367.7 \mathrm{~kg}$ milk in Sweden on the one hand and $3.1 \mathrm{~kg}$ meat in Bangladesh and $3.5 \mathrm{~kg}$ milk in Burundi on the other side; FAO, 2009). In consequence the per capita intake of protein from livestock products varies between 1.7 (Burundi) and $69.0 \mathrm{~g}$ per day (USA) averaging $21.9 \mathrm{~g}$ (FAO, 2009). These figures show the dramatic differentiation between the countries. There is no essential need for food of animal origin, but the consumption of meat, fish, milk and eggs contributes significantly to meet the human requirements in amino acids and some important trace nutrients (such as $\mathrm{Ca}, \mathrm{P}, \mathrm{Zn}, \mathrm{Mn}, \mathrm{Fe}, \mathrm{I}$, Se, vitamins A, D, E, some B-vitamins) esp. for children as well as for pregnant and lactating women. Human nutritionists (Waterlow, 1999; Jackson, 2007) recommend that about one third of the daily protein demand (0.75-1 g per kg body weight; Jackson 2003; Rand et al., 2003) should originate from protein of animal origin. That corresponds to about $20 \mathrm{~g}$ of the daily intake of $60 \mathrm{~g}$ should base on protein of animal origin, which corresponds to the present average consumption (see above). Another reason for foods of animal origin is the generally high availability of the nutrients and their considerable enjoyment value. Such food is also considered as an indicator for the standard of living in many regions of the world. One reason for the higher demand of food of animal origin in some countries (Table 1) is the increased income of the population (Keyzer et al., 2005). 
Feed amounts needed for global animal feeding (without aquaculture) are calculated in Table 2 and compared with human food.

Increasing feed/food demands require higher plant yields (Table 2) or more area for production. Because of some limited resources, low input plants are an important prerequisite to solving future problems and to establishing a sustainable agriculture. Such plants should be very efficient in the use of mineral plant

Table 2. Estimated dry matter (DM) consumption by humans and farm animals (own calculations)

\begin{tabular}{lccc}
\hline Species & $\begin{array}{c}\text { Number } \\
\text { billions; FAO } \\
\text { Stat. 2006 }\end{array}$ & $\begin{array}{c}\text { Consumption } \\
\text { DM } \\
\mathrm{kg} / \mathrm{day}\end{array}$ & $\begin{array}{c}\text { Billion } \\
\text { t/year }\end{array}$ \\
\hline Humans & 6.5 & 0.45 & 1.1 \\
Cattle, buffaloes, horses, camels (large animals) & 1.6 & 8 & 4.6 \\
Sheep, goats (small ruminants) & 1.8 & 1 & 0.7 \\
Pigs & 0.95 & 1 & 0.35 \\
Poultry & 18.5 & 0.07 & 0.45 \\
Total feed & & & \\
$\quad$ presently & & & 6.1 \\
$\quad$ in 2050 & & & \\
Plant yield (required; 1.5 billion ha arable land; & Presently & In 2050 & \\
3.3 billion ha grassland; t DM/ha) & 1.3 & 2.5 & \\
\hline
\end{tabular}

nutrients (including N), fuel, water and arable land (high yields), but they should also be able to very effectively use sun energy and unlimited plant nutrients from the air (such as $\mathrm{N}_{2}$ and $\mathrm{CO}_{2}$; Table 3). Furthermore the genetic pool available in plants, animals and microorganisms should contribute to optimize plants and animals for a more efficient conversion of limited resources into feed and food.

Table 3. Potentials to produce phytogenic biomass and their availability per inhabitant under consideration of the increase of population (Flachowsky, 2010)

\begin{tabular}{lc}
\hline Plant nutrients in the atmosphere, $\mathrm{N}_{2}, \mathrm{CO}_{2}$ & $\uparrow \leftrightarrow$ \\
\hline Sin energy & $\leftrightarrow$ \\
Agricultural area & $\downarrow$ \\
Water & $\downarrow$ \\
Fossil energy & $\downarrow$ \\
Mineral plant nutrients & $\downarrow$ \\
Mineral plant nutrients & $\downarrow$ \\
\hline
\end{tabular}

( $\uparrow$ increase, $\downarrow$ decrease, $\leftrightarrow$ no important influence)

Emissions by animals are another critical points in animal production (Steinfeld et al., 2006). These include N, $\mathrm{P}$ and other minerals from feed, methane $\left(\mathrm{CH}_{4}\right)$ from the anaerobic fermentation of carbohydrates in the anaerobic fermentation in the rumen and other areas (e.g., Baldwin, 1995; Flachowsky and Brade, 2007), 
and carbon dioxide $\left(\mathrm{CO}_{2}\right)$ from fossil fuel. Apart from the low input of limited resources along the food chain a low output of minerals and greenhouse gases $\left(\mathrm{CO}_{2}, \mathrm{CH}_{4}\right.$ and $\left.\mathrm{N}_{2} \mathrm{O}\right)$ during feed/food production are very important aims of sustainable agriculture.

As already mentioned plant breeding and cultivation are the key elements and starting points for feed and food security during the next years (Flachowsky, 2008; SCAR, 2008; The Royal Society, 2009). The most important objectives for plant breeders can be summarized as follows:

- high yields with low external inputs (low input varieties) such as water, minerals, fossil fuel, plant protection substances, etc.

- efficient use of natural unlimited resources such as sun energy, nitrogen and carbon dioxide in the air

- optimize the genetic potential of plants for a highly efficient photosynthesis

- lower concentrations of toxic substances such as secondary plant ingredients, mycotoxins from toxin-producing fungi, toxins from anthropogenic activities or geogenic origin

- lower concentrations of substances that influence the use or bioavailability of nutrients such as lignin, phytate, enzyme inhibitors, tannins, etc.

- higher concentrations of the nutritive value determining components such as nutrient precursors, nutrients, enzymes, prebiotics, essential oils, etc.

From the global view of feed and food security low input varieties have the highest priority. Furthermore, often undesirable substances cannot be removed from feedstuffs, or can only be removed with great effort (Flachowsky, 2006). Therefore decrease of undesirable substances is also an important objective of plant breeding. From the perspective of nutrition, an increase of essential nutrients (e.g., amino acids, fatty acids, trace elements, vitamins, etc.) could be very favourable in some regions of the world to meet the requirements of man and animal with essential nutrients. This aspect is not so important in parts of the world like Europe because of the availability of a large amount of food and feed additives on the market.

It is possible to fulfil the objectives of plant breeding mentioned above by conventional breeding. But in the future methods of biotechnology may be more flexible, more potent and faster. "New" plants, newly expressed proteins in plants and/or changed composition of plants are real challenges for animal and human nutritionists for safety aspects and the nutritional assessment of such products. Table 4 summarizes plant events which are already on the market or which could be commercialized by 2015 on the basis of genetic modification. Some traits are in the direction of low input varieties (e.g., drought tolerance, resistance against 
diseases, etc.), but Table 4 shows also, that we are in the starting phase of this new technology. In 2009 about 134 million ha of GM-plants were cultivated worldwide (about 9\% of total arable land; James, 2009); most of them are tolerant against herbicides and/or resistant against insects. Presently individual interests or interests of some companies are dominating and are not always in agreement with public interests as mentioned above (SCAR, 2008; The Royal Society, 2009). Fundamental research should be conducted by independent publicly sponsored research institutions and the results should be available to all those who are interested in such plants.

Table 4. Events in commercial GM - crops and pipelines worldwide, by trait (Stein and RodriguezCerzo, 2009)

\begin{tabular}{lccccc}
\hline $\begin{array}{l}\text { Trait } \\
\text { Category }\end{array}$ & $\begin{array}{c}\text { Commercial } \\
\text { in 2008 }\end{array}$ & $\begin{array}{c}\text { Commercial } \\
\text { pipeline }\end{array}$ & $\begin{array}{c}\text { Regulatory } \\
\text { pipeline }\end{array}$ & $\begin{array}{c}\text { Advanced } \\
\text { development }\end{array}$ & $\begin{array}{c}\text { Total by } \\
2015\end{array}$ \\
\hline Insect resistance & 21 & 3 & 11 & 22 & 57 \\
Herbicide tolerance & 10 & 4 & 5 & 13 & 32 \\
Crop composition & 0 & 1 & 5 & 10 & 16 \\
Virus resistance & 5 & 0 & 2 & 3 & 10 \\
Abiotic stress tolerance & 0 & 0 & 0 & 5 & 5 \\
Disease resistance & 0 & 0 & 1 & 3 & 4 \\
Nematode resistance & 0 & 0 & 0 & 1 & 1 \\
Fungus resistance & 0 & 0 & 0 & 1 & 1 \\
Other & 2 & 0 & 0 & 11 & 13 \\
note: the number of trails can be bigger than the number of GM crops; & abiotic stress tolerance \\
includes drought tolerance & & \multicolumn{5}{l}{}
\end{tabular}

Assessing the nutritive value and also the safety of foods/feeds from plant breeding and dealing with energy and nutrient requirements of GM animals including animal clones (Niemann and Kues, 2007; Robi et al., 2007) are real challenges for animals nutritionists in the future (Figure 1). Various types of studies are necessary to answer all the questions and to improve the public acceptance of such food/feed and animals, respectively. The current stage of nutritional and safety assessment of feeds from modified plants and future challenges will be analysed in the present paper. Principals of genetic modification of plants as well as socioeconomic and environmental impacts of GM plants (Brookes and Barfoot, 2008) are not covered in the present paper.

\begin{tabular}{|c|c|c|c|c|}
\hline $\begin{array}{l}\text { Plant Breeding } \\
\text { (including genetical } \\
\text { modification) }\end{array}$ & $\vec{t}$ & $\begin{array}{l}\text { Animal nutrition } \\
\text { (nutritional assessment of } \\
\text { feed) }\end{array}$ & $\vec{t}$ & $\begin{array}{l}\text { Animal breeding } \\
\text { (including clones and } \\
\text { GM-animal) }\end{array}$ \\
\hline
\end{tabular}

Figure 1. Animal nutrition (nutritional assessment of feeds) between plant and animal breeding 


\section{PRODUCTION OF MATERIALS FOR ANALYSIS AND FEEDING STUDIES}

Field trials used for production of materials for analyses and feeding studies should be carried out according to the recommendations of EFSA (2006) and ILSI (2003a, 2007).Genetically modified (GM) plants should be cultivated under consideration of specific isolation distances (ILSI, 2007) with their non-GM counterpart or if impossible, with GM parenteral lines as appropriate comparators. The number of locations, growing seasons, geographical spread, replicates and statistical models are important for adequate experimental designs. Apart from the transgenic and its near isogenic counterpart (control), preferably the studies should have four or more conventional (commercial) reference varieties to help explain any unexpected differences or confirm any expected differences observed between the test and control plants (ILSI, 2007). In such a case it is possible to compare the composition and nutritive value of GM-plants with commercial lines. If such a cultivation is impossible, analytical data from the field studies should be compared with literature data (e.g., ILSI, 2003b or updated tables; OECD, 2001a,b, 2002a,b,c, 2003, 2004a,b,c, 2005, or national/local feed value tables).

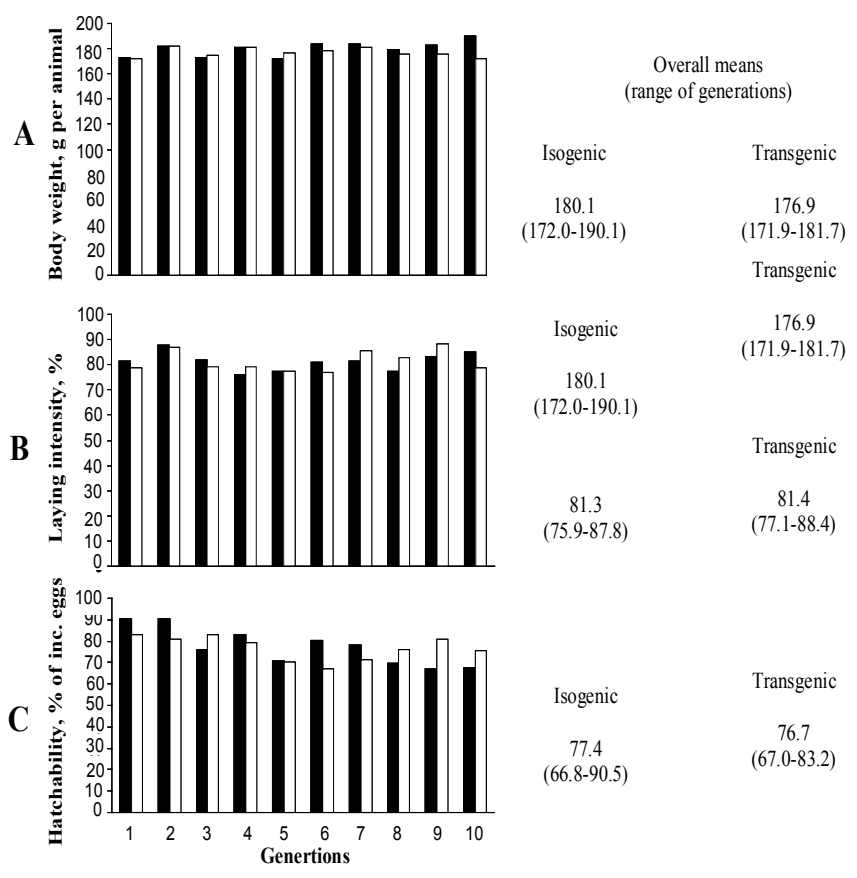

Figure2.A.Bodyweightoffemalequails(age:6weeks),B.layingintensityandC.hatchabilityofquailsfed with isogenic $(\mathbf{\square})$ and transgenic $(\mathrm{Bt}, \square)$ maize in a 10 generations experiment (Flachowsky et al., 2005b) 
But it should also be noted that the specific conditions (season, soil, fertilizer, weather, etc.) might influence the composition of plants or processed materials. Therefore it is always favourable to include adequate comparators in the field studies.

Details of sampling (grain, pasture, hay, silage), handling of samples and preparation of samples for further studies are described by ILSI (2007; Figure 2).

\section{COMPOSITIONAL ANALYSIS}

Before cultivation, during growing, after harvesting, processing and manufacturing of the prepared feed mixture for feeding, the transgenic DNA and the newly expressed protein (or proteins in the case of multi-stacked events) should be tested.

Apart from newly expressed protein, the most important nutrients (Table 5) and antinutritive substances such as pesticides, mycotoxins, enzyme inhibitors, glucosinolates, gossypol and further plant specific toxins should be analysed in the original material and processed substrates and compared with values of the isogenic counterpart, commercial varieties and/or values from food/feed tables. In the present dossiers submitted to the EFSA for application on the European market, between 60 and 100 constituents are analysed in the GM-plants or derived food/feed, its isogenic counterpart and the conventional varieties for comparison. The compositional analysis is an important prerequisite and the cornerstone for the nutritional and safety assessment of food/feed from GMP. This comparative approach is the basis for the concept of substantial equivalence (OECD, 1993) and is suitable to assess GM-plants and derived food/feed of the first generation (GM-plants with input traits). This concept is based on the idea that an existing organism used as food/feed with a history of safe use, can serve as a comparator when assessing the safety of food/feed from GMP. The need of further studies including animal studies depends on the outcome of the compositional approach (for further details see Kok and Kuiper, 2003; EFSA, 2006; FSANZ, 2007. For GM-plants of the second generation (plants with output traits) further steps for safety and nutritional assessment seem to be necessary (see FSANZ, 2007; ILSI, 2007; EFSA, 2008). 
Table 5. Recommendations for Nutrient Analysis (by ILSI, 2007)

\begin{tabular}{|c|c|c|}
\hline Crops/Grains/Coproducts & Livestock type & Analyte $^{1}$ \\
\hline Grain: maize, wheat, barley & Nonruminants & $\begin{array}{l}\mathrm{DM}, \mathrm{CP}, \mathrm{EE}, \mathrm{ADF}, \mathrm{NDF}, \mathrm{Ca}, \mathrm{P}, \mathrm{Mg}, \mathrm{K}, \mathrm{S}, \mathrm{Na}, \mathrm{Cl} \text {, } \\
\mathrm{Fe}, \mathrm{Cu}, \mathrm{Mn}, \mathrm{Zn} \text {, ash, starch, lysine, methionine, } \\
\text { cystine, threonine, trytophan, isoleucine, arginine, } \\
\text { phenylalanine, histidine, leucine, tyrosine, valine, } \\
\text { fatty acids, vitamins }\end{array}$ \\
\hline $\begin{array}{l}\text { Oilseed meals: soyabean, } \\
\text { linseed, cottonseed, canola } \\
\text { meal, full-fat oilseeds }\end{array}$ & Nonruminants & $\begin{array}{l}\mathrm{DM}, \mathrm{CP}, \mathrm{EE}, \mathrm{ADF}, \mathrm{NDF}, \mathrm{Ca}, \mathrm{P}, \mathrm{Mg}, \mathrm{K}, \mathrm{S}, \mathrm{Na}, \mathrm{Cl} \text {, } \\
\mathrm{Fe}, \mathrm{Cu}, \mathrm{Mn}, \mathrm{Zn} \text {, ash, starch, lysine, methionine, } \\
\text { cystine, threonine, trytophan, isoleucine, arginine, } \\
\text { phenylalanine, histidine, leucine, tyrosine, valine, } \\
\text { fatty acids, vitamins }\end{array}$ \\
\hline
\end{tabular}

Grain: maize, wheat, barley Ruminants DM, CP, EE, ADF, NDF, Ca, P,Mg, K, S, Na, Cl, Fe, $\mathrm{Cu}, \mathrm{Mn}, \mathrm{Zn}, \mathrm{Mo}$, ash, starch, ADIN, soluble protein, NPN, degrable protein, NDICP, ADICP, fatty acids, fat soluble vitamins

Oilseed meals: soyabean, Ruminants DM, CP, EE, ADF, NDF, Ca, P,Mg, K, S, Na, Cl, linseed, cottonseed, canola $\mathrm{Fe}, \mathrm{Cu}, \mathrm{Mn}, \mathrm{Zn}$, ash, ADIN, soluble protein, NPN, degrable protein, NDIN, fatty acids, fat soluble vitamins

Seeds: soyabean, cottonseed, Ruminants sunflower

DM, CP, EE, ADF, NDF, Ca, P,Mg, K, S, Na, Cl, $\mathrm{Fe}, \mathrm{Cu}, \mathrm{Mn}, \mathrm{Zn}, \mathrm{Mo}$, ash, ADIN, soluble protein, NPN, degrable protein, NDIN, fatty acids, fat soluble vitamins

Silage: maize, grass, legumes Ruminants

$\mathrm{DM}, \mathrm{CP}, \mathrm{EE}, \mathrm{ADF}, \mathrm{NDF}, \mathrm{Ca}, \mathrm{P}, \mathrm{Mg}, \mathrm{K}, \mathrm{S}, \mathrm{Na}, \mathrm{Cl}$, $\mathrm{Fe}, \mathrm{Cu}, \mathrm{Mn}, \mathrm{Zn}, \mathrm{Mo}$, ash, ADIN, soluble protein, NPN, degrable protein, NDIN, starch, sugar, $\mathrm{pH}$, short chain acids such as lactic, acetic, butyric, isobutyric

Fresh/dry forages: grass, Ruminants $\quad$ DM, CP, EE, ADF, NDF, Ca, P,Mg, K, S, Na, Cl, legumes $\mathrm{Fe}, \mathrm{Cu}, \mathrm{Mn}, \mathrm{Zn}, \mathrm{Mo}$, ash, ADIN, soluble protein, NPN, degrable protein, NDIN, starch, sugar, fatty acids, fat soluble vitamins

${ }^{\top} \mathrm{ADF}$ - acid detergent fibre; ADIN - acid detergent insoluble nitrogen; ADL - acid detergent lignin; ADICP - acid detergent insoluble crude protein; CP - crude protein; DM - dry matter; DNDF digestible neutral detergent fibre; EE - ether extract (crude fat); NDF - neutral detergent fibre; NDICP - neutral detergent insoluble protein; NDIN - neutral detergent insoluble nitrogen; NPN non-protein nitrogen

\section{FEEDING STUDIES}

Before feeding studies compositional analysis and various in silico and in vitro methods (see DBT, 2008; EFSA, 2008) can contribute to the safety assessment of GM-plant derived food and feed. But feeding studies with laboratory and target animals are the key elements for safety and nutritional assessment of food/feed 
from GM-plants.

The following types of feeding studies are established and may be carried out depending on the scientific question:

- laboratory animals models for toxicity testing of single substances (single dose toxicity testing; repeated-dose toxicity testing; reproductive and developmental toxicity testing; immunotoxicity testing, etc. (DBT, 2008; EFSA, 2008)

- laboratory animal models for the safety and nutritional assessment of whole GM-food and feed (in general 90-day feeding studies for safety assessment; to detect unintended effects; subchronic animal tests; for margins of safety, etc. (OECD, 1995; DBT, 2008; EFSA, 2008)

- studies to measure digestibility/bioavailability of nutrients from the GMplants and to analyse the influence of GM-products on the metabolism in target animals/categories (Flachowsky and Böhme, 2005; ILSI, 2007; DBT, 2008; EFSA, 2008)

- tolerance studies to analyse the influence of maximal amounts of GM-feeds on animal health and welfare (ILSI, 2007; DBT, 2008; EFSA, 2008)

- studies with GM-animals to determine the energy and nutrient requirements of modified animals and to analyse quality and safety of food of animal origin

- efficacy studies to measure the influence of GM-feed on animal yield/ performance, feed conversion rate (FCR), slaughtering performance as well as safety and composition of food of animal origin (ILSI, 2007; DBT, 2008; EFSA, 2008)

- long term studies to find out long term effects of GM-feed (e.g., whole growing period in the case of growing animals, whole laying period in the case of laying animals or one or more lactations in the case of lactating animals; whole lifespan of animals; see Table 6)

- multigeneration studies to analyse the influence of GM-feed on fertility/ reproduction performance of animals (BEETLE, 2009).

Table 6. Examples of life spans for growing/fattening animals, in days

\begin{tabular}{lcc}
\hline Animal species/categories & $\begin{array}{c}\text { Conventional/more } \\
\text { intensive }\end{array}$ & $\begin{array}{c}\text { Organic/more } \\
\text { extensive }\end{array}$ \\
\hline Chickens for fattening (broilers) & $3-42$ & $56-84$ \\
Turkeys for fattening & $56-168$ & $70-112$ \\
Growing/fattening pigs & $150-300$ & $200-400$ \\
Veal calves & $80-200$ & - \\
Growing/fattening bulls & $300-500$ & $400-600$ \\
\hline
\end{tabular}

Laying hens and dairy cattle are usually used for longer periods:

- laying hens: about 126-140 days for growing (pullets); about 300-360 days (one year) for the laying period

- dairy cattle: about 22-36 month for growing (heifers); one to ten years for lactation (average in Europe two to five lactations) 
The most important steps to prepare and carry out feeding experiments are summarized in Figure 2. In general the expense of the studies mentioned above increases from the top to the bottom. Therefore long term studies and multigeneration experiments with target animals are very seldom. Limited fed amounts in earlier breeding stadium may also restrict animal numbers and duration of studies with target animals, especially with large animals such as cattle and pigs. In summary the following factors may influence the types of animal feeding studies:

- $\quad$ scientific question(s)

- availability of GM-feeds (especially in early stages of breeding) and adequate comparators

- GM-feed should be included in the diets to the highest possible amounts

- financial budget

- availability of equipments, animals and qualified manpower.

Feeding studies with target animals should be considered in the following paragraphs in more detail. The product quality (e.g., milk, meat, eggs, etc.) should be also measured in the feeding studies or after slaughtering of the animals (ILSI, 2007).

\section{Laboratory animals}

Normally, the OECD guideline tests (OECD, 1995) for chemicals are used for the safety testing of single substances including new products from the genetic modification (e.g., newly expressed proteins; EFSA, 2006, 2008). Mostly rodents (rats or mice) are used over a period of 28 days/one month for single dose or repeated-dose toxicity testing. The detailed testing strategy should be selected on a case-by-case basis based on the prior knowledge regarding the biology of these products, so that relevant endpoints are measured in the individual test (for more details see OECD, 1995; EFSA, 2006, 2008).

A 90-day rodent feeding study should be carried out, when indicated by molecular, compositional, phenotypic, agronomic or other analysis (e.g., changes in metabolic pathways). More details about the necessity of such studies and useful endpoints are described by $\operatorname{OECD}$ (1995) and EFSA $(2006,2008)$.

\section{Target animals}

Studies with target animals are more of nutritional concern. Less attention has presently been paid in such studies to safety aspects (EFSA, 2006, 2008). The type of study depends on the type of genetic modification in the plants or animals and the availability of GM-feed or GM-animals. 


\section{Measuring digestibility/bioavailability}

In the case of substantial changes of composition of plants (GMP with output traits or GMP of the $2^{\text {nd }}$ generation) studies to measure the digestibility/availability of some nutrients or nutrient precursors are necessary (Flachowsky and Böhme, 2005; ILSI, 2007; EFSA, 2008). Mostly such studies are done with model animals (mice, rats, rabbits) or small target animals (chicks, quails, piglets), because of the high costs and the limited feed amounts available in some cases. Table 7 shows results to measure the bioconversion of $\beta$-carotene into vitamin A. The retinol concentration in the liver of Mongolian gerbils as model animals was used as endpoint. The results show that the retinol concentration of liver of gerbils fed with carotene rich maize was similar to animals fed with maize poor in carotene and supplemented with adequate amounts of $\beta$-carotene. That means in this case $B$-carotene from maize is almost identically converted into vitamin $\mathrm{A}$ as supplemented $\beta$-carotene.

Table 7. Experimental design to determine the conversion of $\beta$-carotene into vitamin A in maize ( $60 \%$ of diet, Mongolian gerbils, $n=10$, depletion period: 4 weeks; feeding: 8 weeks; Howe and Tanumihardjo, 2006)

\begin{tabular}{lcccc}
\hline Item & $\begin{array}{c}\text { Unsupplemented } \\
\text { control (maize poor } \\
\text { in carotene) }\end{array}$ & $\begin{array}{c}\text { Carotene } \\
\text { rich maize }\end{array}$ & $\begin{array}{c}\text { Control } \\
+\beta \text { carotene }\end{array}$ & $\begin{array}{c}\text { Control } \\
+ \text { vitamin A }\end{array}$ \\
\hline$\beta$-carotene, nmol/g & 0 & 8.8 & 8.8 & 4.4 \\
Theoretical retinol intake, nmol/d & 0 & 106 & 106 & 106 \\
Retinol in serum, nmol/d & $1.23 \pm 0.20$ & $1.25 \pm 0.22$ & $1.23 \pm 0.20$ & $1.22 \pm 0.16$ \\
Retinol in liver, nmol/d & $0.10^{\mathrm{a}} \pm 0.04$ & $0.25^{\mathrm{b}} \pm 0.15$ & $0.25^{\mathrm{b}} \pm 0.20$ & $0.56^{\mathrm{b}} \pm 0.15$ \\
\hline $\mathrm{a}, \mathrm{b}, \mathrm{c}$ means with different letters differ $(\mathrm{P}<0.05)$ & & &
\end{tabular}

Table 8 . Conventional and low-phytate maize ( $78.5 \%$ of the mixture) in the feed of fattening pigs (from Spencer et al., 2000)

\begin{tabular}{|c|c|c|c|c|}
\hline \multirow{2}{*}{$\begin{array}{l}\text { Item } \\
\text { Inorganic } \mathrm{P} \text { supplement } \\
\mathrm{P} \text { content, } \mathrm{g} / \mathrm{kg}\end{array}$} & \multicolumn{2}{|c|}{$\begin{array}{c}\text { Control } \\
0.3 \text { g of available } \\
\text { P per kg } \\
\end{array}$} & \multicolumn{2}{|c|}{$\begin{array}{c}\text { Low-phytate maize } \\
1.7 \mathrm{~g} \text { of available } \\
\text { P per kg }\end{array}$} \\
\hline & - & + & - & + \\
\hline $\begin{array}{l}\text { 29-73 kg liveweight } \\
73-112 \mathrm{~kg} \text { liveweight }\end{array}$ & $\begin{array}{l}3.4 \\
3.2\end{array}$ & $\begin{array}{l}5.4^{1} \\
4.7\end{array}$ & $\begin{array}{l}3.4 \\
3.2\end{array}$ & $\begin{array}{l}5.4^{1} \\
4.7^{2}\end{array}$ \\
\hline Feed intake, kg/d & $2.23^{\mathrm{a}}$ & $2.50^{\mathrm{b}}$ & $2.53^{\mathrm{b}}$ & $2.51^{\mathrm{b}}$ \\
\hline Liveweight gain, g/day & 730 & $870^{\mathrm{b}}$ & $900^{\mathrm{b}}$ & $880^{\mathrm{b}}$ \\
\hline Feed per gain, $\mathrm{kg} / \mathrm{kg}$ & $3.05^{\mathrm{a}}$ & $2.87^{\mathrm{b}}$ & $2.81^{\mathrm{b}}$ & $2.85^{\mathrm{b}}$ \\
\hline $\mathrm{P}$ excreted, $\mathrm{g} / \mathrm{kg}$ & $4.6^{\mathrm{a}}$ & $8.9^{\mathrm{c}}$ & $3.8^{\mathrm{b}}$ & $8.8^{\mathrm{c}}$ \\
\hline Strength, $4^{\text {th }}$ metacarpal bone, $\mathrm{kg}$ & $79.3^{\mathrm{a}}$ & $138.5^{\mathrm{bc}}$ & $132.2^{\mathrm{b}}$ & $153.9^{c}$ \\
\hline Ash content, $\%$ in $4^{\text {th }}$ metacarpal bone & $53.5^{\mathrm{a}}$ & $60.1^{\mathrm{bc}}$ & $59.3^{\mathrm{b}}$ & $61.2^{\mathrm{c}}$ \\
\hline
\end{tabular}


Similar studies are necessary to demonstrate the efficacy of enzymes expressed in plants or to show the higher phosphorus availability in plants with a lower phytate content. Phytate is one of the most important inhibitors of P-availability. In a pig study (Table 8) low phytate maize showed the same results as traditional maize supplemented with 2 or $1.5 \mathrm{~g}$ inorganic P per kg feed, but a significantly lower P-excretion.

\section{Efficacy trials}

Many feeding studies were carried out during the last years to show the substantial equivalence (OECD, 1993) of feed from GM-plants of the first generation (without substantial changes in their composition or GMP + '.' with input traits). Most of the studies were done as efficacy trials and GM-feed were compared in adjusted diets with their isogenic counterparts and some

Table 9. Some recommendations from the "Best practices for the conduct of animal studies to evaluate crops genetically modified for input traits (GMP of the first generation)"; adapted from ILSI (2003a)

\begin{tabular}{|c|c|c|c|c|}
\hline $\begin{array}{l}\text { Animals } \\
\text { species/categories }\end{array}$ & $\begin{array}{l}\text { Number of animals } \\
\text { coefficient of } \\
\text { variation } 4 \text { to } 5 \%\end{array}$ & $\begin{array}{l}\text { Duration of } \\
\text { experiments }\end{array}$ & $\begin{array}{l}\text { Composition } \\
\text { of diets }{ }^{1}\end{array}$ & Measurements \\
\hline $\begin{array}{l}\text { Poultry for meat } \\
\text { production }\end{array}$ & $\begin{array}{l}10 \text { to } 12 \text { pens per } \\
\text { treatment with } 9 \text { to } \\
12 \text { birds per pen }\end{array}$ & 5 weeks or more & $\begin{array}{l}\text { Balanced } \\
\text { diets }\end{array}$ & $\begin{array}{l}\text { Feed intake, } \\
\text { gains, feed } \\
\text { conversion }\end{array}$ \\
\hline $\begin{array}{l}\text { Poultry for egg } \\
\text { production }\end{array}$ & $\begin{array}{l}12 \text { to } 15 \\
\text { replications per } \\
\text { treatment with } 3 \text { to } \\
5 \text { layers per pen }\end{array}$ & $\begin{array}{l}18 \text { to } 40 \text { weeks of } \\
\text { age, at least three } \\
28 \text {-day phases }\end{array}$ & $\begin{array}{l}\text { Balanced } \\
\text { diets }\end{array}$ & $\begin{array}{l}\text { Feed intake, egg } \\
\text { production, feed } \\
\text { conversion, egg } \\
\text { quality }\end{array}$ \\
\hline Swine & $\begin{array}{l}6 \text { to } 9 \text { replications } \\
\text { per treatment with } \\
4 \text { or more pigs per } \\
\text { replication }\end{array}$ & $\begin{array}{l}\text { Piglets }(7-12 \mathrm{~kg}), \\
4-6 \text { weeks } \\
\text { Growers }(15-25 \mathrm{~kg}) \\
6-8 \text { weeks }\end{array}$ & $\begin{array}{l}\text { Balanced } \\
\text { diets }\end{array}$ & $\begin{array}{l}\text { Feed intake, gain, } \\
\text { feed conversion, } \\
\text { carcass quality }\end{array}$ \\
\hline $\begin{array}{l}\text { Growing } \\
\text { and finishing } \\
\text { ruminants }\end{array}$ & $\begin{array}{l}6 \text { to } 10 \text { replications } \\
\text { per treatment with } \\
6 \text { or more cattle per } \\
\text { replication }\end{array}$ & $90-120$ days & $\begin{array}{l}\text { Balanced } \\
\text { diets }\end{array}$ & $\begin{array}{l}\text { Feed intake, gain, } \\
\text { feed conversion, } \\
\text { carcass data }\end{array}$ \\
\hline $\begin{array}{l}\text { Lactating dairy } \\
\text { cows }\end{array}$ & $\begin{array}{l}12-16 \text { cows per } \\
\text { treatment } \\
28 \text { cows per } \\
\text { treatment }\end{array}$ & $\begin{array}{l}\text { Latin square: } 28 \\
\text { day periods } \\
\text { Randomized block } \\
\text { design }\end{array}$ & $\begin{array}{l}\text { Balanced } \\
\text { diets }\end{array}$ & $\begin{array}{l}\text { Feed intake, milk } \\
\text { performances } \\
\text { and composition, } \\
\text { body weight, } \\
\text { Body Condition } \\
\text { Score (BCS), cell } \\
\text { counts in milk, } \\
\text { animal health. }\end{array}$ \\
\hline
\end{tabular}

'efficacy studies to evaluate feed from GMP with output traits (GMP of the second generation) should be done under consideration of recommendation by EFSA (2008) and ILSI (2007) 
conventional commercial varieties (one to ten in some cases). The experimental designs were used according to the recommendations by ILSI (2003a, 2007; see Table 9) and EFSA (2006, 2008). Questions concerning the tolerance of some feeds in animals (tolerance studies) may be also included in efficacy trials.

During the last few years some reviews on nutritive and safety assessment of feeds from GM-plants (mostly plants from the first generation) were published (e.g., Clark and Ipharraguerre et al., 2001; Flachowsky and Aulrich, 2001; Aumaitre et al., 2002; Flachowsky et al., 2005a, 2007; CAST, 2006). Furthermore the documents by ILSI $(2003 a, 2007)$ and $\operatorname{EFSA}(2006,2008)$ also summarize the present stage of knowledge in feeding of feeds from GM-plants to target animals. The animal studies did not show biologically relevant differences between animals fed with feed from GMP or their isogenic counterparts. Transgenic DNA and newly expressed proteins showed adequate properties as normal plant-DNA and proteins and are degraded during feed treatment and in the digestive tract of animals (Flachowsky et al., 2005a; Alexander et al., 2007; see Table 10).

More studies are necessary for nutritional assessment of food/feed from the second generation of GMP (plants with substantial changes in composition see Tables 7 and 8). Experimental designs for such studies are described in detail by EFSA (2006, 2008), Flachowsky and Böhme (2005) and ILSI (2007).

Table 10. Performance and some metabolic parameters of the $1^{\text {st }}$ and $2^{\text {nd }}$ lactation of a long-term feeding study with dairy cows ( $\mathrm{n}=18$ per treatment, 25 months with Bt-maize (MON 810, 63\% of roughage, $41 \%$ of concentrate from maize; Steinke et al., 2009) ${ }^{1}$

\begin{tabular}{|c|c|c|c|c|c|c|}
\hline \multirow{2}{*}{ Lactation } & \multicolumn{2}{|c|}{$1^{\mathrm{st}}$} & \multirow{2}{*}{ P-level } & \multicolumn{2}{|c|}{$2^{\text {nd }}$} & \multirow{2}{*}{ P-level } \\
\hline & isogenic & transgenic & & isogenic & transgenic & \\
\hline Dry matter intake, $\mathrm{kg} / \mathrm{d}$ & 18.7 & 18.9 & 0.532 & 21.0 & 20.4 & 0.080 \\
\hline Milk yield, $\mathrm{kg} / \mathrm{d}$ & 23.9 & 23.7 & 0.566 & 29.2 & 28.8 & 0.419 \\
\hline Milk fat, $\%$ & 3.95 & 4.03 & 0.015 & 3.75 & 3.86 & 0.055 \\
\hline Milk protein, $\%$ & 3.62 & 3.71 & $<0.001$ & 3.59 & 3.56 & 0.299 \\
\hline $\mathrm{NEFA}, \mu \mathrm{mol} / 1$ & 287 & 281 & 0.991 & 292 & 290 & 0.988 \\
\hline $\mathrm{BHBA}, \mathrm{mmol} / \mathrm{l}$ & 0.46 & 0.44 & 0.107 & 0.50 & 0.49 & 0.304 \\
\hline $\mathrm{AST}, \mathrm{U} / 1$ & 92.6 & 89.8 & 0.263 & 94.3 & 88.8 & 0.177 \\
\hline GLDH, U/1 & 19.5 & 19.1 & 0.922 & 13.8 & 16.1 & 0.178 \\
\hline$\gamma-\mathrm{GT}, \mathrm{U} / 1$ & 23.2 & 23.9 & 0.426 & 23.5 & 23.9 & 0.575 \\
\hline
\end{tabular}

${ }^{1}$ no fragments of Cry1Ab DNA in blood, milk, faeces and urine of cows; traces of Cry1 Ab protein were detected in faeces, but not in blood, milk and urine (Gürtler et al., 2009)

\section{Long term feeding studies}

Long term feeding studies cover the whole lifespan of the animals (see Table 6) or a very long period of their life, e.g., in the case of laying hens or dairy cows. Answers expected from such studies include, apart from the animal's performance their fertility and health, if fed with high amounts of GM-feed. Can animal 
feeding trials contribute to the assessment of long term effects? This was the main question of the BEETLE-study (2009). The assessment of the data and the results from the Online Survey of BEETLE (2009) on animal health did not show any new aspects. Some participants of the Online Survey expect only potential long term effects in relation to allergenicity of man, but all other possible adverse long term effects were assessed as negligible. In general a methodical improvement of the risk assessment procedure has been recommended including a higher number of replications and additional control groups to demonstrate the biological range of measured parameters.

After publishing the BEETLE-study (2009) a long term feeding study with dairy cows (two lactations; Spiekers et al., 2009) was finished and partially published (see Table 10). Dry matter intake, milk yield and composition as well as physiological parameters in cows were not significantly influenced by feeding of high amounts GM-maize (MON 810). Fragments of the newly expressed protein and of the tDNA were not detected in samples of animal tissues and in the milk.

\section{Multigeneration studies}

In addition to long term feeding studies, multigeneration studies were carried out to test the reproduction and long term health effects in laboratory and target animals. In laboratory animals no negative effects were described on testicular cells or reproductive traits in mice fed Bt maize or a glyphosate tolerant soyabean compared with conventional maize or soyabean (Brake and Evenson, 2004; Brake et al., 2004). Rats and their pupils were not significantly influenced in a five generation study, if fed with 5\% GM potatoes with the bar gene or conventional potatoes (Rhee et al., 2005). Kilic and Akay (2008) did not find any differences in the organ weights of the offspring and no differences in reproduction rate of rats fed up to $20 \% \mathrm{Bt}$ maize or conventional maize.

In a ten generation study with laying quails fed diets containing $50 \% \mathrm{Bt}$ maize did not significantly influence production and reproduction performances of animals compared with a diet containing $50 \%$ isogenic maize.

The outcome of three studies with mice (strain OF1, Austrian mice study; Velimirov et al., 2008), including a multi-generation study, a reproductive assessment by continuous breeding and a life time study, fed with diets containing 33\% NK603 x MON810 maize or its isogenic counterpart was discussed controversially because of weaknesses in experimental design, calculation errors and methodical deficiencies in the statistical analysis (Afssa, 2009; EFSA, 2009). Later (March 2010) the study was withdrawn from the Internet by the Austrian officials (Table 11). 
Table 11. Comments to some studies which certain disturbances after feeding GM-crops

\begin{tabular}{|c|c|c|c|}
\hline Authors & Study & Results & Comments \\
\hline $\begin{array}{l}\text { Nordlee et al., } \\
1996\end{array}$ & $\begin{array}{l}\text { Transgen of paranut in } \\
\text { soyabean and maize }\end{array}$ & $\begin{array}{l}\text { Allergenic reactions in } \\
\text { man }\end{array}$ & $\begin{array}{l}\text { Scientific study, no practical } \\
\text { relevance }\end{array}$ \\
\hline $\begin{array}{l}\text { Ewen and Pusztai } \\
1999\end{array}$ & Lectin potatoes to rats & $\begin{array}{l}\text { Influence of intestinal } \\
\text { tract, disturbance of } \\
\text { reproduction }\end{array}$ & $\begin{array}{l}\text { Scientific study, no practical } \\
\text { relevance }\end{array}$ \\
\hline $\begin{array}{l}\text { Maletesta et al., } \\
2002,2003\end{array}$ & $\begin{array}{l}\text { RR soyabean to mice: } \\
\text { comparison with wild } \\
\text { variety }\end{array}$ & $\begin{array}{l}\text { Increased cell nucleus } \\
\text { in liver and pancreas }\end{array}$ & $\begin{array}{l}\text { Methodical weaknesses, } \\
\text { comparison with wild } \\
\text { variety, What is normal? } \\
\text { Relevance of results? }\end{array}$ \\
\hline Hemre et al., 2005 & $\begin{array}{l}\text { RR soyabean } \\
\text { to salmon }\end{array}$ & $\begin{array}{l}\text { Increase of spleen, } \\
\text { influence of spleen } \\
\text { functions, more smaller } \\
\text { erythrocytes }\end{array}$ & $\begin{array}{l}\text { What is normal? } \\
\text { Repetition of study }\end{array}$ \\
\hline $\begin{array}{l}\text { McNaughton } \\
\text { et al., } 2007\end{array}$ & $\begin{array}{l}\text { Maize event } \\
\text { DAS-59122-7 } \\
\text { in broilers }\end{array}$ & $\begin{array}{l}\text { No differences, but liver } \\
\text { of female rats was } \\
3 \mathrm{~g} / \mathrm{kg} \text { heavier }(\mathrm{P}<0.05)\end{array}$ & $\begin{array}{l}\text { Values in physiological } \\
\text { range; overestimation of } \\
\text { data; What is normal? } \\
\text { Statistical significance, but } \\
\text { biological not relevant }\end{array}$ \\
\hline $\begin{array}{l}\text { Poulsen et al., } \\
2007 \mathrm{a}, \mathrm{b}\end{array}$ & $\begin{array}{l}\text { Feeding transgenic } \\
\text { lectin-rice to rats }\end{array}$ & $\begin{array}{l}\text { Disturbances in } \\
\text { development and } \\
\text { fertility }\end{array}$ & $\begin{array}{l}\text { Scientific study, no practical } \\
\text { relevance }\end{array}$ \\
\hline $\begin{array}{l}\text { Seralini et al., } \\
2007\end{array}$ & $\begin{array}{l}\text { New analysis of the rat } \\
\text { feeding study by the } \\
\text { notifier (Monsanto) } \\
\text { with MON } 863\end{array}$ & $\begin{array}{l}\text { Some differences } \\
\text { in liver and kidney } \\
\text { parameters }\end{array}$ & $\begin{array}{l}\text { Critical analysis of the } 90 \\
\text { days rat study, differences } \\
\text { not directed, statistical } \\
\text { significant, but biological } \\
\text { not relevant (see Doull et } \\
\text { al., 2007) }\end{array}$ \\
\hline $\begin{array}{l}\text { Scholtz et al., } \\
2008\end{array}$ & $\begin{array}{l}\text { Feeding of } 50 \% \text { Bt- } \\
\text { maize in longterm } \\
\text { study in qualils }\end{array}$ & $\begin{array}{l}\text { Differences in some } \\
\text { enzymatic activities } \\
\text { between both groups }\end{array}$ & $\begin{array}{l}\text { Physiological relevance, } \\
\text { what is normal? Other } \\
\text { results after repetition of } \\
\text { study }\end{array}$ \\
\hline Surov, 2009 & $\begin{array}{l}3 \text { generations study } \\
\text { with hamsters, added } \\
\text { GM-soyabean to } \\
\text { the diet, } 5 \text { pairs per } \\
\text { treatment }\end{array}$ & $\begin{array}{l}\text { Lower reproduction of } \\
\text { hamsters fed with GM } \\
\text { soyabean }\end{array}$ & $\begin{array}{l}\text { Presently no scientific } \\
\text { publication; only } \\
\text { preliminary report, scientific } \\
\text { assessment not possible }\end{array}$ \\
\hline $\begin{array}{l}\text { Velimirov et al., } \\
2008\end{array}$ & $\begin{array}{l}\text { Long term reproduction } \\
\text { studies in mice fed } \\
\text { transgenic corn } \\
\text { NK603xMON810 }\end{array}$ & $\begin{array}{l}\text { Some disturbances in } \\
\text { reproduction of mice }\end{array}$ & $\begin{array}{l}\text { For comments see above; } \\
\text { with drawn be the Austrian } \\
\text { officials }\end{array}$ \\
\hline $\begin{array}{l}\text { De Vendomois et } \\
\text { al., } 2009\end{array}$ & $\begin{array}{l}\text { Reanalysis of } 90 \text { day } \\
\text { rat feeding studies with } \\
\text { corn varieties MON 863, } \\
\text { MON 810, NK } 603\end{array}$ & $\begin{array}{l}\text { More significant } \\
\text { differences than reportet } \\
\text { by the notfier } \\
\text { (Monsanto) }\end{array}$ & $\begin{array}{l}\text { Weaknesses in the statistical } \\
\text { methods used for reanalysis } \\
\text { (see Doull et al., 2007) }\end{array}$ \\
\hline
\end{tabular}




\section{Comments to some feeding studies}

There is large agreement that studies with feeds from GM-plants of the first generation (with input traits) did not significantly influence animal health, performance, composition and quality of animals products (summaries by Alexander et al., 2007; Flachowsky et al., 2007; BEETLE, 2009). On the other hand there are some studies mainly carried out with laboratory animals, but in some cases also with target species, which show contraversial results (Table 11). They are a basis for public discussions. In some cases the authors tested GM-feed with antinutritive substances (e.g., Nordlee et al., 1996; Ewen and Pusztai, 1999; Poulsen et al., 2007a,b) in fundamental research studies. Such feeds or feed spiked with antinutritive materials do not have any pratical relevance and no chance of coming onto the market because of the strong regulations for safety assessment (EFSA, 2006, 2008). In other cases GMfeeds in the diet have been compared with wild varieties (e.g., Malatesta et al., 2002, 2003). Wild varieties of legumes contain various antinutritive substances (e.g., enzyme inhibitors) and differences between both treatments must be expected (Table 11). Table 11 contains further studies or reassessments of studies (e.g., Seralini et al., 2007; De Vendomis et al., 2009) with some disturbances and comments to the results. Nevertheless, despite of weaknesses of some studies (Table 11) some authors (e.g., Dona and Arvanitoyannis, 2009) use the results uncritically and deduce health risks only from the application of genetically modified food/feed. Conflicting results in different studies indicate that there is a need for further research.

Side effects might be expected in GMP, especially in GMP with multiple modifications (multi-stacked events; Cellini et al., 2004) and must be analysed in detail on scientific basis. Furthermore the high biological range for many parameters should be considerd. Presently, no other food/feed are so extensively analysed and tested in various studies as GMP-products. It can be concluded, that the safety and nutritional evaluation of GM versus conventionally bred plants is not well balanced (Kok et al., 2008).

\section{FUTURE TRENDS}

Presently, GM-plants which are tolerant against some herbicides or resistant against insects (Stein and Rodriguez-Cerezo, 2009) are dominating on the market (Table 12). 
Table 12. Assessment of present modifications of plants from the view of food safety and food security

\begin{tabular}{lccc}
\hline \multirow{2}{*}{ Objectives } & Present & \multicolumn{2}{c}{ Contributions to } \\
\cline { 3 - 4 } & significance & food safety & global food security \\
\hline More resistant against herbicides & $\Uparrow \Uparrow \Uparrow$ & $\Uparrow$ & $\Uparrow$ \\
More resistant against insects, etc. & $\Uparrow \Uparrow$ & $\Uparrow$ & $\Uparrow$ \\
e.g., European maize borer & & & $(\Uparrow)$ \\
More valuable ingredients & $\Uparrow$ & $\sim$ & $\Uparrow$ \\
Less undesirable ingredients & $(\Uparrow)$ & $\Uparrow \Uparrow$ & $\Uparrow \Uparrow \Uparrow$ \\
More efficient use of resources, water, etc. & $(\Uparrow)$ & $\Uparrow$ &
\end{tabular}

$\Uparrow \Uparrow \Uparrow-$ extremely high; $\Uparrow \Uparrow-$ very high; not important

But there are various trends for future objectives of plant breeding and development of GM-plants (see Table 4). The combination of some stacks to unify favourable properties in one hybrid is presently very popular in plant breeding (EFSA, 2007; Stein and Rodriguez-Cerzo, 2009). In 2009 about 20\% of the global area cultivated with GM-plants was stacked events (James, 2009). Plants with four stacks are already in the regulatory pipeline (Table 13), more stacked plants are in the breeders gardens.

Table 13. GM-maize stacks and their regulatory situation in the EU (Stein and Rodriguez-Cerco, 2009);

\begin{tabular}{lcccc}
\hline Stacking & $\begin{array}{c}\text { Number stacks of } \\
\text { world wide* }\end{array}$ & Authorised & $\begin{array}{c}\text { EU situation } \\
\text { pending }\end{array}$ & Under assessment \\
\hline Double & 13 & 4 & 1 & 8 \\
Triple & 3 & 4 & 1 & 2 \\
Quadruple & 1 & 0 & 0 & 1 \\
\hline * total number of the commercial GMmaize stacks and the GM maize stacks in the commercial and \\
regulatory pipeline. Due to the differences in the regulation of stacks events on a global scale there \\
may be more (implicity) authorised GM maize available)
\end{tabular}

Apart from stacking further objectives of plant breeding are in the pipeline of breeding companies and may be summarized as follow:

- improvement of nutritional properties (e.g., amino acids, fatty acids, minerals, vitamins, enzymes, lower content of undesirable compounds)

- higher resistance against biotic and abiotic stressors

- more efficient use of limited natural resources (water, arable land, fuel nutrients, etc.).

It is quite clear from the view of animal nutrition that studies to measure the bioavailability of changed nutrients are necessary. But:

- do we need feeding trials within target animals with stacked events (see EFSA, 2007)? 
- do we need feeding trials with GM-plants, which use resources (e.g., water, abiotic stressors) more efficiently, but without changes in composition?

There exist some open questions regarding the feeding studies with GManimals. Furthermore feeding studies with target animals should be used more intensively for safety assessment of food/feed from GM-plants.

\section{CONCLUSIONS}

Feeding studies with feed from genetically modified plants contribute substantially to safety and nutritional assessment of such feeds. Presently feeding studies with laboratory animals have been mainly used for safety assessment, those with target animals for nutritional assessment. Studies with target animals should also be used more intensively for safety assessment in future.

New developments in plant and animal breeding will be real challenges for animal nutritionists in the nutritional and safety assessment of such products.

\section{REFERENCES}

$<$ Afssa (Agence Francaise de Securite Sanitaire des Aliments), 2010. AVIS de affsa sur l'étude de Velimirow et al., « effets biologiques de la consommation du mais transgenique NK603xMON810 dans des études de reproduction a long terme chez la souris ». Maisons-Alfort, 12.03.209; Saisine n 2008-SA-0361, pp. 5>

$<$ Alexander T.W., Reuter T., Aulrich K., Sharma R., Okine E.K., Dixon W.T., McAllister T.A., 2007. A review of the detection and fate of novel plant molecules derived from biotechnology in livestock production. Anim. Feed Sci. Tech. 133, 31-62>

$<$ Aumaitre A., Aulrich K., Chesson A., Flachowsky G., Piva G., 2002: New feeds from genetically modified plants: Substantial equivalence, nutritional equivalence, digestibility, and safety for animals and the food chain. Livest. Prod. Sci. 74, 223-238>

$<$ Baldwin R.L., 1995. Modelling Ruminant Digestion and Metabolism. Chapman \& Hall Ltd., London (UK)>

$<$ BEETLE, 2009. Long-term effects of genetically modified (GM) crops on health and the environment (including biodiversity). Executive Summary and Main Report. Federal Office of Consumer Protection and Food Safety (BVL), Berlin, pp. $132+6$ Annexes>

$<$ Brake D.E., Evenson D.P., 2004. A generational study of glyphosate-tolerant soybeans on mouse fetal, postnatal and adult testicular development. Food Chem. Toxicol. 42, 29-36>

Brake D.G., Thaler R., Evenson D.P., 2004. Evaluation of Bt (Bacillus thuringiensis) maize on mouse testicular development by dual parameter flow cytometry. J. Agr. Food Chem. 52, $2097-$ 2102

Brookes G., Barfoot P., 2008. GMcrop: Global Socio-Economic and Environmental Impacts 19962006. PG Economics Ltd., Dorchester (UK), pp. 118

CAST, 2006. Safety of Meat, Milk, and Eggs from Animals fed Crops Derived from Modern Biotechnology. No 34, pp.8 
Cellini F., Chesson A., Coquhonn I., Constable A., Davies H.V., Engel K.-H., Gatehouse A.M.R., Kärenlampi S., Kok E.J., Legnay J.J., Lehesranta S., Noteborn H.P.J.M., Pedersen J., Smith M., 2004. Unintended effects and their detection in genetically modified crops. Food Chem. Toxicol. 42, 1089-1123

Clark J.H., Ipharraguerre I.R., 2001. Livestock performance: Feeding biotech crops. J. Dairy Sci. 84, E Suppl., E9-E18, 237-249

DBT (Department Biotechnology), 2008. Protocols for Food and Feed Safety Assessment of GE Crops. Department of Biotechnology, Ministry of Science and Technology, India, pp. 34

De Vendomois J.S., Roullier F., Cellier D., Seralini G.-E., 2009. A comparison of te effects of three GM corn varieties om mammalian health. Int. J. Biol. Sci. 5, 706-726

Dona A., Arvanitoyannis I.S., 2009. Health risks of genetically modified foods. Ritcal Rev. Food Sci. Nutr. 49, 164-175

Doull J., Gaylor D., Greim H.A., Lovell D.P., Lynch B., Munro I.C., 2007. Report of an Expert Panel on the reanalysis of Seralini et al., (2007) of a 90-day study conducted by Monsanto in support of the safety of a genetically modified corn variety (MON 863). Food Chem. Toxicol. 45, 2073-2085

EFSA, 2006. Guidance document of the Scientific Panel on Genetically Modified Organisms for the risk assessment of genetically modified plants and derived food and feed. EFSA J. 99, 1-100

EFSA, 2007. Guidance document of the Scientific Panel on Genetically Modified Organisms for the risk assessment of genetically modified plants containing stacked transformation events. EFSA J. 512, 1-5

EFSA, 2008. Safety and nutritional assessment of GM plant derived food and feed. The role of animal feeding trials. Food Chem. Toxicol. 46, 2-70

EFSA, 2009. GMO Panel deliberations on the Austrian report "Biological effects of transgenic maize NK603 x MON810 fed in long term reproduction studies in mice". Adopted at the 47th Plenary Meeting, Parma, 28-29 January 2009, p. 1

Ewen S.W.B., Pusztai A., 1999. Effects of diets containing genetically modified potatoes expressing Galanthus nivalis lectin on rat small intestine. Lancet, 354. 1353-1354

FAO, 2009. The state of food and agriculture - Livestock in the balance. Food and Agriculture Organization of the United Nations, Rome, pp. 180

Flachowsky G. (Editor), 2006. Possibilities of decontamination of "Undesirable substances of Annex 5 of the Feed Law (2006)" (in German), Landbauforsch. Völkenrode - FAL Agr. Res., Special Issue 294, pp. 290

Flachowsky G., 2008. What do animal nutritionists expect from plant breeding? Outlook Agr. 37, 95-103

Flachowsky G., 2010. Global food security: Is there any solution? (in German). NovoArgumente 105-3-4, 64-68

Flachowsky G., Aulrich K., 2001. Nutritional assessment of GMO in animal nutrition. J. Anim. Feed Sci. 10, Suppl. 1, 181-194

Flachowsky G., Aulrich K., Böhme H., Halle I., 2007. Studies on feeds from genetically modified plants (GMP) Contributions to nutritional and safety assessment. Anim. Feed Sci. Tech. 133, $2-30$

Flachowsky G., Böhme H., 2005. Proposals for nutritional assessments of feed from genetically modified plants. J. Anim. Feed Sci. 14, 49-70

Flachowsky G., Brade W., 2007. Potentials to reduce methane emissions in ruminants (in German). Züchtungskunde 79, 417-365

Flachowsky G., Chesson A., Aulrich K., 2005a. Animal nutritional with feeds from genetically modified plants. Arch. Anim. Nutr. 59, 1-40 
Flachowsky G., Dänicke S., 2005. From feed to safe food - Contributions of animal nutrition to the safety of food. In: A.P. Riley (Editor). New Developments in Food Policy, Control and Research. Nova Science Publ. Inc., pp. 65-95

Flachowsky G., Halle I., Aulrich K., 2005b. Long term feeding of Bt-corn - a ten generation study with quails. Arch. Anim. Nutr. 59, 449-451

FSANS, 2007. The role of animal feeding studies in the safety assessment of genetically modified foods. Report of Workshop of Food Standards. Australia, New Zealand, 15th June 2007, Canberra, p. 19

Gürtler P., Paul V., Steinke K., Preisinger W., Wiedemann S., Albrecht C., Spiekers H., Schwarz F., Meyer H.H.D., 2009. Investigations on the potential transfer of recombinant DNA and Cry1 Ab protein from feed into milk, blood, feces and urine of cows fed genetically modified maize. Proc. Soc. Nutr. Physiol. 18, 111 (Abstr.)

Hemre G.-I., Sanden M., Bakke-McKellep A.M., Sagstad A., Krogdahl A., 2005. Growth, feed utilization and health of Atlantic salmon Salmo salar L. fed genetically modified compared to non-modified commercial hybrid soybeans. Aqucult. Nutr. 11, 157-167

Howe J.A., Tanumihardjo S.A., 2006. Cartenoid-biofortified maize maintains adequate vitamin A status in Mongolian gerbils. J. Nutr. 136, 2562-2567

ILSI, 2003a. Best practices for the conduct of animal studies to evaluate crops genetically modified for input traits. International Life Sciences Institute, Washington, DC, p. 62 http//www.ilsi.org/ file/bestpracticescas.pdf.

ILSI, 2003b. Crop Compositional Database. Accessed 200

ILSI, 2007. Best practices for the conduct of animal studies to evaluate crops genetically modified for output traits. Int. Life Sci. Inst., Washington, DC

Jackson A.A., 2007. Protein. In: J. Mann and S. Truswell (Editors). Essential in Human Nutrition. $3^{\text {rd }}$ Edition. Oxford University Press, pp. 53-72

James C., 2009. Global status of commercialised transgenic crops: 2009. ISAAA. Ithaca, NY, http:// www.isaaa.org..

Kebreab E., Clark K., Wagner-Riddle K., France J., 2006. Methane and nitrous oxide emissions from Canadian agriculture. A review. Can. J. Anim. Sci. 86, 135-158

Keyzer M.A., Merbis M.D., Pavel L.F.P.W., van Wesenbeck C.F.A., 2005. Diets shifts towards meat and the effect on cereal use: Can we feed the animals in 2030. Ecol. Econ. 55, 187-202

Kilic A., Akay M.T., 2008. A three generation study with genetically modified Bt corn in rats: Biochemical and histopathological investigation. Food Chem. Toxicol. 46, 1164-1170

Kok E., Kuiper H., 2003. Comperative safety assessment of biotech crops. Trends Biotech. 21, 439-444

Kok E.J., Keijer J., Kleter G.A., Kuiper H.A., 2008. Comparative safety assessment of plant-derived feeds. Reg. Toxicol. Pharmacol. 50, 98-113

Malatesta M., Caporaloni C., Gavaudan S., Rocchi M., Serafini S., Tiberi C., Gazzanelli G., 2002. Ultrastructural morphometrical and immunocytochemical analyses of hepatocyte nucleus from mice fed on genetically modified soybean. Cell Struct. Funct. 2, 173-180

Malatesta M., Caporaloni C., Rossi L., Battistelli S., Rocchi M., Tonucci F., 2003. Malatesta M., Caporaloni C., Rossi L., Battistelli S., Rocchi M., Tonucci F., 2003. Ultrastructural analysis of pancreatic acinar cells from mice fed on genetically modified soybans. J. Anat. 201, 409-415

McNaughton I.L., Roberts M., Rice D., Smith B., Hinds M., Schmidt J., Locke M., Bryant A., Rood T., Layton R., Lamb I., Pelaney B., 2007. Feeding performance of broiler chickens fed diets containing DAS-59122-7 maize grain compared to diets containing nontransgenic maize grain. Anim. Feed Sci. Tech. 132, 227-239 
Munkvold G.P., Hellmich R.L., Rice L.G., 1999. Comparison of Fumonisin concentrations in kernels of transgenic Bt-maize hybrids and nontransgenic hybrids. Plant Dis. 83, 130-138

Niemann H., Kues W., 2007. Transgenic farm animals: An update. Reprod. Fert. Develop. 19, 762770

Nordlee J.A., Taylor S.L., Townsend J.A., Thomas L.A., Bush R.K., 1996. Identification of a Brasil nut allergen in transgenic soybeans. N. Engl. J. Med. 334, 688-692

OECD, 1993. Safety evaluation of foods derived by modern biotechnology. Concepts and principles, OECD Paris (France)

OECD, 1995. OECD Guidelines for the testing of chemicals. OECD Cons. Meeting, 02./03November 1995, Rome; OECD, Paris (France)

OECD, 2001a. Series on the Safety of Novel Foods and Feeds No. 1. Consensus document on key nutrients and key toxicants in low erucic acid rapeseed (canola). OECD, Paris (France)

OECD, 2001. Series on the Safety of Novel Foods and Feeds No. 2: Consensus document on compositional considerations for new varieties of soybean: Key food and feed nutrients and anti-nutrients. OECD, Paris (France)

OECD, 2002a. Series on the Safety of Novel Foods and Feeds No. 3: Consensus document on compositional considerations for new varieties of sugar beet: Key food and feed nutrients and anti-nutrients. OECD, Paris (France)

OECD, 2002b. Series on the Safety of Novel Food and feed No. 4. Consensus document on compositional considerations for new varieties of potatoes: key food and feed nutrients and anti-nutrients and toxicants. OECD, Paris (France)

OECD, 2002c. Series on the Safety of Novel Foods and Feeds No. 5: Consensus document on compositional for new varieties of maize (Zea mays): Key food and feed nutrients and antinutrients and secondary metabolites. OECD, Paris (France)

OECD, 2003. Series on the Safety of Novel Food and feed No. 7. Consensus Document on Compositional Considerations for New Varieties of Bread Wheat (Triticum aestivum): Key Food and Feed Nutrients, Anti-Nutrients and Toxicants. OECD, Paris (France)

OECD, 2004a. Series on the Safety of Novel Food and feed No. 10. Consensus Document on Compositional Considerations for New Varieties of Rice (Oryza sativa): Key Food and Feed Nutrients and Anti-Nutrients. OECD, Paris (France)

OECD, 2004b. Series on the Safety of Novel food and feed No. 11. Consensus Document on Compositional Considerations for New Varieties of Cotton (Gossypium hirsutum and Gossypium barbadense): Key Food and Feed Nutrients and Anti-Nutrients. OECD, Paris (France)

OECD, 2004c. Series on the Safety of Novel Food and feed No. 12. Consensus Document on Compositional Considerations for New Varieties of Barley (Hordeum vulgare L.): Key Food and Feed Nutrients and Anti-nutrients. OECD, Paris (France)

OECD, 2005. Series on the Safety of Novel Food and feed No. 13. Consensus Document on Compositional Considerations for New Varieties of Alfalfa and other Temperate Forage Legumes: Key Feed Nutrients, Anti-nutrients and Secondary Plant Metabolites. OECD, Paris (France)

Poulsen M., Kroghsbo S., Schroder M., Wilcks A., Jacobsen H., Miller A., Frenzel T., Danier J., Rychlik M., Shu Q., Emami K., Sudhakar D., Gatehouse A., Engel K.H., Knudsen I., 2007a. A 90-day safety study in Wistar rats fed genetically modified rice expressing snowdrop lectin Galanthus nivalis (GNA). Food Chem. Toxicol. 45, 350-363

Poulsen M., Schroder M., Wilcks A., Kroghsbo S., Lindecrona R.H., Miller A., Frenzel T., Danier J., Richlik M., Shu Q., Emami K., Taylor M., Gatehouse A., Engel K.H., Knudsen I., 2007b. Safety testing of GM-rice expressing PHA-E lectin using a new animal test design. Food Chem. Toxicol. 45, 364-377 
Rand W.M., Pellett P.L., Young V.R., 2003. Meta-analysis of nitrogen balance studies for estimating protein requirements in healthy adults. Amer. J. Clin. Nutr. 77, 109-127

Rhee G.S., Cho D.H., Won Y.H., Soek J.H., Kim S.S., Kwack S.J., Lee R.D., Chae S.Y., Kim J.W., Lee B.M., Park K.L., Choi K.S., 2005. Multigeneration reproductive and developmental toxicity study of bar gene inserted intogenetically modified potato on rats. J. Toxicol. Environ. Health 68, 2263-2276

Robi J.M., Wang P., Kasinathan P., Kuroiwa P., 2007. Transgenic animal production and biotechnology. Theriogenology 67, 127-133

SCAR (EU Commission - Standing Committee on Agricultural Research, 2008. New challenges for agricultural research. Climate change, rural development, agricultural knowledge systems. The $2^{\text {nd }}$ SCAR Foresight Exercise, Brussels, December 2008, pp. 112

Scholtz N., Müller U., Halle I., Flachowsky G., Sauerwein H., 2008. Metabolic and histological traits in quails fed with either transgenic $(\mathrm{Bt})$ or with isogenic maize for several generations. Proc. Soc. Nutr. Physiol. 17, 105 (Abstr.)

Seralini G.-E., Cellier D., de Vendomris J.S., 2007. New analysis of rat feeding study with a genetically modified maize reveals signs of hepatorenal toxicity. Arch Environ. ContSpiekers H., Meyer H.H.D., Schwarz F.J., 2009. Effects of long term utilzation of genetically modified maize (MON 810) in dairy cattle feeding on performance and metabolism parameters (in German). Schriftenreihe, Bayerische Landesanstalt für Landwirtschaft (LfL), 18, p. 105

Spencer J.D., Allee G.L., Sauber T.E., 2000. Phosphorus bioavailablity and digestibility of normal and genetically modified low-phytate com for pigs. J. Anim. Sci. 78, 675-681

Spiekers H., Meyer H.H.D., Schwarz F.J., 2009. Effects of long term utilzation of genetically modified maize (MON 810) in dairy cattle feeding on performance and metabolism parameters (in German). Schriftenreihe, Bayerische Landesanstalt für Landwirtschaft (LfL), 18, p. 105

Stein A.J., Rodriguez-Cerezo E., 2009. The global pipeline of new GM-crops. JRC/ipts, EUR 23496 EN, p. 102

Steinfeld H., Gerber P., Wassenaar T., Castel V., Rosales M., de Haan C., 2006. Livestock's long shadow: Environmental issues and options. Food Agriculture Organization of the United Nations (FAO), Rome

Steinke K., Paul V., Gürtler P., Preisinger W., Wiedemann S., Albrecht C., Spiekers H., Meyer H.H.D., Schwarz F.J., 2009. Effects of long term feeding of genetically modified maize (Btmaize; MON810) to dairy cows on performance and metabolic parameters. Proc. Soc. Nutr. Physiol. 18, 110 (Abstr.)

Surov A.V., 2009. Alteration of physiological characteristics of mammals at feeding with genetically modified components of plant origin. Report on Scientific-Technical Study, Institute of RussianAcademy of Science, Moscow

The Royal Society, 2009. Reaping the benefits: Science and the sustainable intensification of global agriculture. RS policy document 11/09, issued October 2009 RS 1608, ISBN: 978-0-85403784-1

Velimirov A., Binter C., Zentek J., 2008. Biological effects of transgenic maize NK603xMON810 fed in long term reproduction studies in mice. Res. Report Section IV, Vol.3/2008 of the Bundesministerium für Gesundheit, Familie und Jugend, Sektion IV, Vienna (Austria)

Waterlow J.C., 1999. The mysteries of nitrogen balance. Nutr. Res. Rev. 12, 25-54 